\title{
Effect of water softening on the colour intensity of routine haematoxylin and eosin stain
}

S.R. Malkawi, ${ }^{1}$ R.M. Abu-Hazeem ${ }^{1}$ and M.O. Easa ${ }^{1}$

$$
\begin{aligned}
& \text { تأثير يُيْرِة المياه على شدة التلوُّن بعلوّن الليماتو كسيلين والأيوزين الروتيني }
\end{aligned}
$$

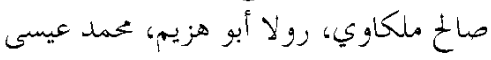

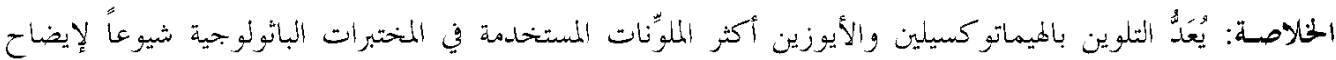

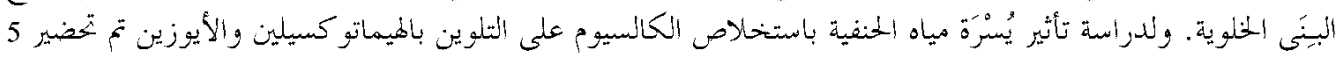

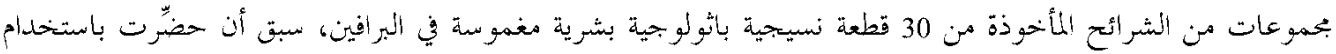

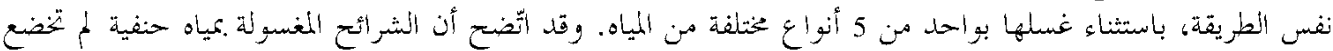

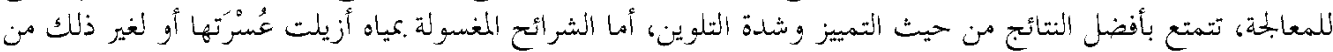

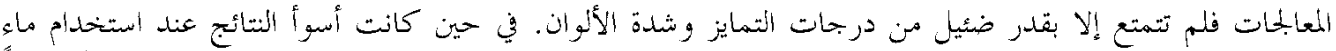

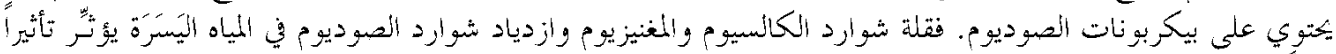

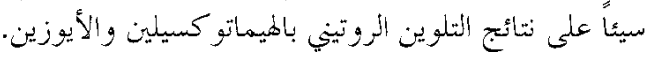

ABSTRACT Haematoxylin and eosin (H\&E) is the most popular routine stain used in pathology laboratories for highlighting cellular structures. To study the effect of tap water 'softening' (i.e. calcium extraction) on H\&E stains, 5 sets of slides from 30 different paraffin-embedded human pathologic tissue blocks were prepared in the same way except for washing with 5 different types of water. Slides washed in untreated tap water showed the best results concerning differentiation and colour intensity, while slides washed with softened or other treated water showed poorer degrees of differentiation and colour intensity. The worst results were obtained from slides washed with water containing sodium bicarbonate. Low calcium and magnesium ions and high sodium ions in soft water adversely affect the results of routine H\&E stain.

Effet de l'adoucissement de l'eau sur l'intensité de la couleur de la coloration de routine à l'hématoxyline-éosine

RESUME L'hématoxyline et l'éosine sont les colorations les plus couramment utilisées dans les laboratoires de pathologie pour la mise en évidence des structures cellulaires. Afin d'étudier l'effet de l'adoucissement de l'eau du robinet (extraction du calcium) sur les colorations à l'hématoxyline et à l'éosine, cinq (5) séries de lames issues de 30 blocs de tissus pathologiques humains différents inclus en paraffine ont été préparées de la même manière, sauf pour le lavage qui a été effectué avec cinq types d'eau différents. Les lames lavées à l'eau du robinet non traitée ont montré les meilleurs résultats pour ce qui concerne la différenciation et l'intensité de la couleur, tandis que les lames lavées à l'eau adoucie ou avec une autre eau traitée affichaient des degrés plus faibles de différenciation et d'intensité de la couleur. Les plus mauvais résultats ont été obtenus avec les lames lavées à l'eau contenant du bicarbonate de sodium. La teneur faible en ions calcium et magnésium et élevée en ions sodium de l'eau douce affecte négativement les résultats de la coloration de routine à l'hématoxyline-éosine.

${ }^{1}$ Princess Iman Research and Laboratory Sciences Centre, King Hussein Medical Centre, Amman, Jordan.

Received: 27/05/02; accepted: 21/04/03

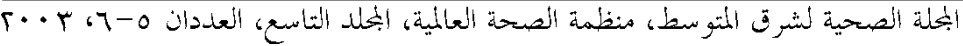




\section{Introduction}

Haematoxylin and eosin (H\&E) is the most widely applied routine stain in the histopathology laboratory because of its ability to highlight tissue structures and because it is an inexpensive, quick method that is readily available as powders or ready-to-use solutions.

Haematoxylin stain is extracted from the logwood of a tropical tree, Haematoxylon campechianum [1]. The nuclei of cells are stained by its active product, haematin, which is produced when an oxidizing agent is added. Haematin by itself has poor affinity to stain nuclei without combining with a mordant, such as aluminium, iron or other metallic salts. Ripened haematoxylin can stain nuclei by electrostatic attraction between its positive-charged ions with the negative-charged contents in the nucleus such as phosphate groups in DNA and RNA and carboxylated or sulfated mucosubstances $[2,3]$.

Eosin is an anionic dye that is usually used as a counterstain to haematoxylin. It can stain cytoplasmic organelles by electrostatic attraction with positive-charged ions in tissues such as collagen or muscle.

Many factors affect the colour intensity of a stain, including the type of mordant, the duration of each step in the staining process, tissue fixation methods, $\mathrm{pH}$ and many others. One of these factors may be the tap water used for washing slides during processing. At the laboratories of the King Hussein Medical Centre in Jordan, it was noticed that H\&E stained slides washed with 'softened' (treated) water became faint compared with those previously washed with 'hard' (untreated) tap water. This led us to make a systematic comparison of different types of treated tap water on the colour intensity of slides and to in- vestigate changes in the chemical content of tap water before and after treatment.

\section{Methods}

A total of 30 different human pathology tissue specimens embedded in paraffin blocks, previously fixed in 10\% buffered formalin, were processed routinely for histopathology. The tissue specimens included samples from the endometrium, appendix, gall bladder, spleen and other gastric and pleural tissues obtained by surgery, curettage and biopsy. Five sections ( $5 \mu \mathrm{m}$ thick) were prepared from each paraffin block and placed on different slides. The slides were divided into 5 groups. Each group was stained routinely with H\&E stain under the same conditions except that different waters were used for the washing steps:

- tap water (untreated),

- soft water (treated tap water),

- $1 \%$ magnesium sulfate $\left(\mathrm{MgSO}_{4}\right)$ dissolved in soft water,

- $1 \%$ calcium carbonate $\left(\mathrm{CaCO}_{3}\right)$ dissolved in soft water, or

- $1 \%$ sodium bicarbonate $\left(\mathrm{NaHCO}_{3}\right)$ dissolved in soft water.

The following H\&E staining procedure was applied:

1. De-wax slides in xylene.

2. Hydrate sections by applying different concentrates of ethyl alcohol $(70 \%$, $85 \%, 95 \%$ up to absolute alcohol).

3. Wash in water.

4. Stain in Coles haematoxylin stain for 8 min.

5. Wash in water for $20 \mathrm{~s}$.

6. Differentiate in $1 \% \mathrm{HCl}$ dissolved in $70 \%$ alcohol for $10 \mathrm{~s}$.

7. Wash in water for $20 \mathrm{~s}$. 
8. Blue in Scott's tap water solution for 1 min.

9. Wash in water for $1 \mathrm{~min}$.

10. Stain in $0.5 \%$ eosin yellowish for $3 \mathrm{~min}$.

11. Wash in water for $30 \mathrm{~s}$.

12. Dehydrate through different concentrates of alcohol, clear in xylene, and permanent mount with distrene-plasticizer-xylene (DPX) synthetic resin.

All stained slides were reviewed microscopically and evaluated for adequacy of H\&E stain, taking into consideration the degree of differentiation, background stain and the overall intensity of colour in comparison with slides washed in untreated tap water.

Finally, water samples were taken from the Kind Hussein Medical Centre before and after water softening and the chemical composition was analysed by the Water Authority of Jordan to measure specific conductance, $\mathrm{pH}$ and the concentrations of various ions and heavy metals.

\section{Results}

Slides washed in raw untreated tap water showed good differentiation and good colour intensity for both the blue colour of haematoxylin and red colour of eosin. This group of slides washed in tap water was used as a reference of colour intensity and differentiation.

Slides washed in soft (treated) tap water, showed faint blue colour and very faint to almost absence of reddish colour of eosin with poor differentiation (Figure 1). Slides washed in $1 \% \mathrm{MgSO}$ dissolved in soft water showed slightly faint blue colour, faint red colour of eosin with moderate differentiation (Figure 2). Slides washed in $1 \% \mathrm{CaCO}_{3}$ dissolved in soft water showed slightly faint blue colour, and very faint red colour of eosin with poor dif-

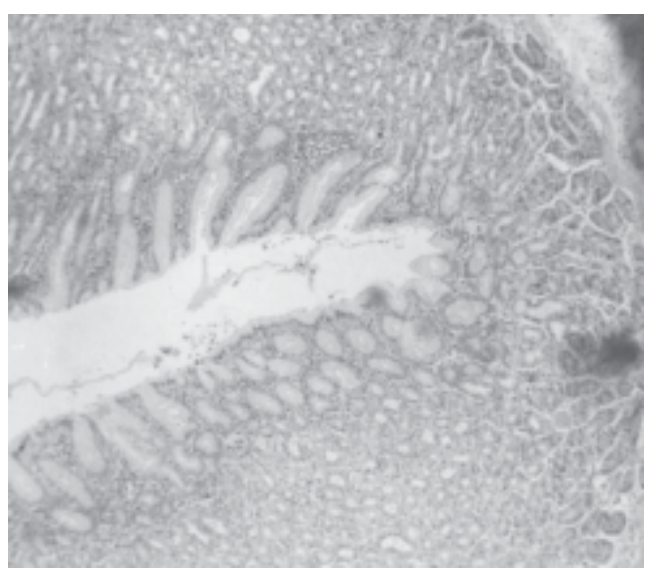

Figure 1 Stained slide from colon specimen treated with soft water

ferentiation. The worst results were obtained from slides washed in sodium bicarbonate $\left(1 \% \mathrm{NaHCO}_{3}\right.$ dissolved in soft water). They showed very faint blue colour, and very faint to almost absence of red colour of eosin with poor differentiation.

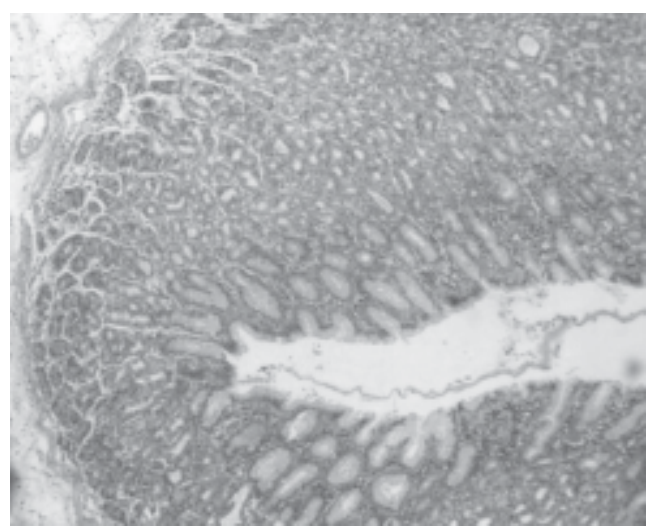

Figure 2 Stained slide from appendix specimen treated with magnesium sulfate in soft water

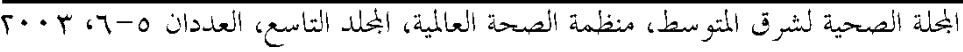


Table 1 shows the chemical composition of water samples taken from the King Hussein Medical Centre before and after water softening. The amount of sodium ions increased after water softening from $1.65 \mathrm{mEq} / \mathrm{L}$ in tap water to $7.98 \mathrm{mEq} / \mathrm{L}$ in soft water, and the $\mathrm{pH}$ of soft water became slightly more alkaline (from 7.60 to 8.02).

\section{Discussion}

Tap water contains large amounts of ions such as calcium, magnesium and many other minerals that make it 'hard' [4]. As calcium and magnesium cations are rela- tively insoluble in water, they tend to precipitate out as calcium carbonate, causing scale and deposit problems in heat exchange equipment, boilers and pipelines. 'Hardness' of water is the concentration of calcium and magnesium ions expressed in terms of calcium carbonate. The amount of hardness in natural waters may vary from $60 \mathrm{mg} / \mathrm{L}$ to over $180 \mathrm{mg} / \mathrm{L}$ calcium carbonate. The main purpose of water softening in big centres, hospitals and modern houses is to eliminate calcium and magnesium ions, which are replaced by sodium ions.

The increase in sodium ions as well as the slightly more alkaline $\mathrm{pH}$ of soft water shown here may be responsible for the de-

\begin{tabular}{|c|c|c|}
\hline Chemical analysed & $\begin{array}{l}\text { Before } \\
\text { softening }\end{array}$ & $\begin{array}{c}\text { After } \\
\text { softening }\end{array}$ \\
\hline Specific conductance $(\mu \mathrm{S} / \mathrm{cm})$ & 814 & 850 \\
\hline pH (units) & 7.60 & 8.02 \\
\hline \multicolumn{3}{|l|}{ lons } \\
\hline Calcium by titration (mEq/L) & 4.40 & 0.00 \\
\hline Magnesium by calculation (mEq/L) & 2.18 & 0.02 \\
\hline Sodium by flame photometry (mEq/L) & 1.65 & 7.98 \\
\hline Potassium by flame photometry (mEq/L) & 0.07 & 0.01 \\
\hline Chloride by titration $(\mathrm{mEq} / \mathrm{L})$ & 3.01 & 2.88 \\
\hline Sulfate by titration (mEq/L) & 0.75 & 0.75 \\
\hline Carbonate by titration $(\mathrm{mEq} / \mathrm{L})$ & 0.00 & 0.00 \\
\hline Bicarbonate by $\mathrm{H}_{2} \mathrm{SO}_{4}$ titration $(\mathrm{mEq} / \mathrm{L})$ & 4.18 & 4.09 \\
\hline Nitrate by spectrophotometry ( $\mathrm{mg} / \mathrm{L}$ as $\mathrm{NO}_{3}$ ) & 30.71 & 30.61 \\
\hline \multicolumn{3}{|l|}{ Heavy metals } \\
\hline Iron (mg/L) & 0.05 & 0.03 \\
\hline Manganese (mg/L) & 0.015 & 0.013 \\
\hline Copper (mg/L) & $<0.01$ & $<0.01$ \\
\hline Lead (mg/L) & $<0.01$ & $<0.01$ \\
\hline Chromium (mg/L) & $<0.01$ & $<0.01$ \\
\hline Cadmium (mg/L) & $<0.003$ & $<0.01$ \\
\hline Zinc (mg/L) & 0.17 & 0.01 \\
\hline Nickel (mg/L) & $<0.01$ & $<0.01$ \\
\hline
\end{tabular}

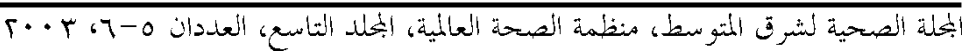


terioration in the colour intensity of H\&E stain, mainly in the eosin red stain which became faint or almost absent. It is highly recommended to use raw untreated tap water for washing steps in the routine H\&E stain and consideration should be given to the effect of soft water on other stains.

\section{Acknowledgements}

We would like to thank Miss N. AbuHazeem and engineer A-A. Al-Ajarmeh for their support. The technical support of the Water Authority of Jordan is highly appreciated.

\section{References}

1. Stevens A. The haematoxylins. In: Bancroft JD, Stevens A, eds. Theory and practice of histological techniques. Edinburgh, Churchill Livingstone, 1982: 109-21.

2. Baker JR, ed. Principles of biological microtechnique. London, Methuen, 1958: 238-41.
3. Singer M. Staining of tissue sections with acid and basic dyes. International reviews of cytology, 1952, 1:211-55.

4. Water sources and impurities. In: Handbook of industrial water conditioning, 8th ed. Trevose, Pennsylvania, USA, Betz Laboratories, 1980:10-3.

\section{Mote from the Editor}

We would like to draw our readers' attention to the evaluation form at the end of this issue. We welcome comments from our readers, which can help us improve the EMHJ. We would appreciate it therefore if readers could kindly take the time to complete this form and return it to us. Alternatively, the form can be completed on line at: http://www.emro.who.int/publications/emhj/evaluationform.asp

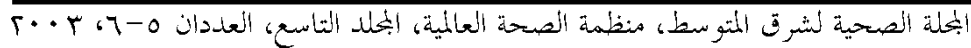

